Јелена Гинић

Филолошки факултет УБ

811.161 .1 '34

https://doi.org/10.18485/mks_knsjkk.2017.ch5

\section{ФОНЕТСКИ СТЕРЕОТИП И УЏБЕНИЦИ РУСКОГ ЈЕЗИКА У СРБИЈИ}

Корпус за ексцерпирање грађе (фонетског материјала) за наше истраживање били су неки од актуелних уџбеника руског језика за основну школу: за други страни језик (уџбенички комплет Орбита), за први страни језик (уџбенички комплет Родничок). У корпус су ушли и уџбеници за основну школу 60-их и 70-их година XX века у коауторству Петра Митропана. Они су нам послужили за повлачење паралела са савременим уџбеницима у вези с квантитетом, квалитетом и учесталошћу фонетског материјала. Из уџбеничких комплета ексцерпирали смо комплетан фонетски материјал који се тиче фонетских објашњења и фонетских вежби, подвргнувши га квантитативној, квалитативној и фреквенцијској анализи. Задатак квантитативне анализе био је да покаже удео фонетског материјала у целокупном уџбеничком материјалу, при чему смо правили разлику између сегментног и супрасегментног (прозодијског) материјала; задатак квалитативне анализе био је да покаже квалитет самих описа и квалитет вежби које се односе на фонетски материјал, док је задатак фреквенцијске анализе био да нам укаже на то који фонетски материјал доминира конкретним уџбеничким комплетом.

Узевши у обзир доминантни сегментни и супрасегментни материјал анализираних уџбеничких комплета обе генерације, дошли смо до закључка да централно место припада гласовима [ч'], [j], [ш':], [ж], [ш], [ц], [л] и [ы], које називамо фонетским стереотипом. Сматрамо да поменути гласови, иако важни за усвајање, не завређују по квантитету и учесталости у уџбеницима место које им припада. Пошто су, традиционално, доминирали у старијим уџбеницима, а новији су продужавали искуство старијих, десило се да исти фонетски материјал доминира и генерацијом новијих уџбеника. Тематизацију датих гласова у овој мери сматрамо стереотипном: у оба језика имамо слич не гласове и пажњу треба указивати само на разлике у квалитету. Савремени уџбеници морали би, бар у погледу фреквенције, тематизовати доминантно следећи фонетски материјал: опозиције тврд/мек сугласнички глас, за којима треба да следе акцентовани и редуковани вокалски гласови, ИК-3 и специфична сегментација, пошто их артикулациона база српског језика не познаје и оне представљају огромну тешкоћу за изворне говорнике српског језика.

Кључне речи: фонетски материјал, уџбеници руског језика у Србији, артикулациона база, фонетски стереотип.

${ }^{1}$ jelena.ginic@fil.bg.ac.rs ; jelenaginic@gmail.com
1. Артикулациона база руског језика у односу на српску

1.1.Тешкоће у овладавању изговором једног језика у целини лакше се превазилазе уколико се овлада специфичностима артикулационе базе руског језика. Шта је сама артикулациона база? Како овладати артикулационом базом? Артикулациона база најједноставније се дефинише као „скуп устаљених говорних навика”, или „свеукупност изговорних тенденција” (Ахманова 1966: 55) изворних говорника једног језика. Иако неки аутору сматрају да описи артикулационе базе остају више на нивоу утисака (Кодзасов, Кривнова 2001: 313), данас су, ипак, конкретне особености артикулационе базе руског језика дефинисане. Још је J. А. Бризгунова 1963. године говорила о конкретним карактеристикама артикулационе базе руског језика, не посматрајући артикулациону базу само у „односу на одређене еталоне гласова и артикулационе покрете већ и у односу на читаву гласовну организацију речи, синтагме и фразе" (Логинова 2004: 14). Неке од карактеристика руске артикулационе базе експлициране су у уџбеницима С. В. Књазева и С. К. Пожарицке (2005: 144; 2011: 189-190) .

1.2.Тешко је овладати у потпуности артикулационом базом било ког страног језика. Овладати артикулационом базом руског језика би, у ствари, значило научити руски језик без примеса страног акцента, што може бити постављено као циљ само на студијама русистике, али нисмо сигурни да може бити и остварено, поготово у домену прозодије. Међутим, да би се сама настава фонетског материјала исправно поставила, морали бисмо знати све (или бар оне познате) особености које формирају руску артикулациону базу и њен однос према српској, како бисмо правилно дефинисали опсег фонетског материјала у програмима, а затим, према њима, артикулисали и опсег и интензитет фонетског материјала у уџбеницима руског језика у српској говорној средини.

1.3. Од једанаест карактеристика руске артикулационе базе које су наведене у уџбеницима С. В. Књазева и С. К. Пожарицке, шест се директно тичу прозодијских јединица и средстава. Управо се у овим карактеристикама које ћемо у тексту навести разликују карактеристике артикулационе базе српског језика у односу на руски. Како би се исправно формирале прозодијске навике и 
умења, морамо имати у виду следеће, за говорнике српског језика, тешке за усвајање особености руске артикулационе базе у односу на српску: постојање „палатализације” као појаве у савременом руском језику (правилан изговор палатализованих гласова кључан је фактор за правилан изговор наредног акцентованог или неакцентованог вокалског гласа); постојање неједнородних вокалских акцентованих гласова, дифтонгоида и полифтонгоида у руском језику (српски језик овакве гласове не познаје, стога говорник српског језика мора да усваја нове навике у вези с „отвореношћу”, односно „затвореношћу” конкретних вокалских гласова); постојање специфичне ритмике речи; постојање акценатског језгра које обухвата акцентовани и први предакцентовани слог; постојање узлазно-силазног мелодијског кретања тона с наглим узалазним покретом тона и почетком пада у оквиру истог вокалског гласа; могућност брзог пребацивања (рус. „переключение”) с једног типа артикулације на други (меки сугласнички гласови могу да стоје поред тврдих гласова) (Князев, Пожарицкая 2005: 144; 2011: 189-190), или: „лакоћа прелаза с режима палатализације на режим непалатализације, лакоћа алтернирања „тврдих” и „меких" слогова у оквиру исте речи (Корниенко 1995: 52).

1.4. Додали бисмо још две особине које наведени аутори нису убројали у скуп устаљених говорних навика, па самим тим ни у одлике руске атикулационе базе, које дати репертоар одлика руске артикулационе базе у односу на српску допуњују: постојање квантитативне и квалитативне редукције неакцентованих вокалских гласова; постојање великог броја реалних и психолошких пауза у оквиру исказа.

1.5. Особине које приближавају српску и руску артикулациону базу су: концентрисаност артикулација сугласничких гласова у усној дупљи (нема увуларних, фарингалних, епиглоталних и ларингалних гласова); чешће су дорзалне језичке артикулације у односу на апикално-алвеоларне; регресивно усмерене асимилације; велики вокалски простор (од предњег реда гласа [и] до задњег реда гласова [o] и [у]); постојање фонационих разлика по тону, одсуство фонационих разлика према напрегнутости и аспирацији; неизразитост слоговних граница.
1.6. На питање колико уџбеници руског језика у Србији одражавају ове битне особине артикулационе базе руског језика битне за изворне говорнике српског, шта тематизују, у којој мери, колико квалитетно и колико често, потрудићемо се да одговоримо у следећем, истраживачком делу рада.

2. Начин анализе фонетског материјала уџбеничких комплета Родничок и Орбита, и уџбеника у коауторству Петра Митропана (основна школа). Фонетска доминанта (вођица)

2.1. Фонетски материјал у уџбеницима руског језика анализирали смо на следећи начин: прво смо вршили квантитативну анализу, која нам је разоткривала удео фонетског материјала у целокупном материјалу уџбеника, показивала колико је места посвећено сегментним јединицама и средствима, колико прозодијским, колико је места посвећено теоријским објашњењима у вези са сегментним и прозодијским јединицама и средствима, а колико вежбама појединих јединица и средстава. Потом смо вршили квалитативну анализу, дајући критичко-аналитичке коментаре у вези с квалитетом презентације и вежби фонетског материјала, као и предлоге за унапређење самих објашњења или вежби.

2.2. Коначно смо, према уџбеничком комплету Родничок, чији фонетски материјал је први анализиран, шифровали сваки детаљ специјалног фонетског материјала који се презентује или увежбава у конкретној лекцији, назвавши га фонетском (сегментном или прозодијском) доминантом или вођицом (наш термин). Шифровање фонетских доминанти омогућило нам је фреквенцијску анализу (на нивоу целог уџбеничког комплета, не сваке лекције појединачно), која нам је показала које се фонетске јединице или средства у ком уџбеничком комплету најчешће понављају. Дата анализа пружила нам је материјал за обиље закључака разне врсте: зашто су одређене фонетске доминанте фреквентне, а друге не, да ли се фреквенција фонетских доминанти разликује између актуелних уџбеничких комплета, као и да ли има неке разлике између актуелних уџбеничких комплета и оних који су се користили седамдесетих година (на примеру уџбеника Петра Митропана) покушали да објаснимо зашто одређене, врло важне доминанте, потпуно изостају. 
2.3. Због ограниченог простора нећемо представити шифровање фонетских доминанти сваког комплета појединачно, табеле којима показујемо квантитет фонетског материјала, табеле с фреквенцијом материјала учитавом комплету, нити квалитативна запажања у вези са сваком конкретном јединицом фонетског материјала, већ ћемо резултате представити у облику закључака које смо на основу истраживања (пропраћеног мноштвом табела) извели, наводећи најважније коментаре који се тичу квалитета тематизованог фонетског материјала.

\section{3. Фонетски материјал уџбеничког комплета Родничок}

\section{1. Родничок 1-Родничок 4}

3.1.1 После квантитативне анализе можемо закључити да аутори овог комплета у нижим разредима основне школе подразумевају много рада на правилном изговору, усавршавању акцентуације и интонације, много више него што бисмо могли закључити према презентацији фонетског материјала у самом уџбенику². Квантитативна анализа разраде сваког часа у оквиру приручника препоручује у просеку 11,3 минута рада на фонетском материјалу (од укупних 45 минута колико траје час), што задоваљава стандарде пратећег фонетског курса. Квантитативна анализа указала нам је на значајно место које аутори придају фонетском материјалу, задовољавајући квалитет обраде у уџбенику и приручнику.

3.1.2. Када се фокусирамо на прозодијски материјал који је у овим комплетима презентован, можемо закључити да је он минимално присутан: у вези с прозодијским средством „акценат”, обрађује се само редукција вокалских гласова, изговор акцентованог гласа [ы] и ритмика речи. Изостају многе крупне партије које се тичу прозодијског материјала, а о којима смо писали у делу о артикулационој бази. Интонација се, као фонетско средство у ужем смислу, не помиње. Замерке које бисмо упутили квалитету

\footnotetext{
${ }^{2}$ Од велике важности у анализи фонетског материјала за ниже разреде били су приручници за наставнике. У њима је детаљно описан сваки део часа, с препорученим оквирним временским интервалом.
}

описа фонетског материјала у комплетима Родничок 1-Родничок 4 тичу се, пре свега, недовољне прецизности самих фонетских описа, недовољног броја специфичних фонетских вежби за редукцију гласова (која се по први пут помиње у комплету Родничок 3, а озбиљније и детаљније обрађује у комплету Родничок 4) и ритмику речи (једино помињање у комплету Родничок 4). Уџбеник и радна свеска комплета Родничок 3 и Родничок 4 су целокупно акцентоване (присутан је графички знак за акценат), што сматрамо добром страном ових комплета.

\section{2. Родничок 5}

3.2.1. Специјални фонетски материјал заступљен у уџбенику је недовољан и квантитативно и квалитативно: квантитативна анализа фонетског материјала уџбеника нам показује да је специјалном материјалу посвећено врло мало места (око 4,5\% у односу на укупан материјал уџбеника). У фонетском материјалу доминирају сегментна објашњења (2,9\% у односу на укупни материјал уџбеника). Све сегментне доминанте су праћене одређеним сегментним вежбама, за разлику од прозодијских доминанти. Радна свеска се састоји од низа, најчешће, условно-комуникативних вежби с граматичким вежбама и вежбама превођења, без ужег увежбавања фонетског материјала. Фонетске доминанте које се обрађују у петом разреду су веома налик на уџбенике 70. година у коауторству Петра Митропана о којима ће бити речи касније.

3.2.2. Готово да потпуно одсуствују прозодијске доминанте: обрађује се само једна прозодијска доминанта (недовољно квантитативно и квалитативно заступљена): редукција вокалских гласова после тврдих и меких сугласничких гласова; у потпуности одсуствују прозодијске вежбе, док је прозодијских објашњења веома мало (свега 0,4\% у просеку по лекцији). Прозодијска објашњења су заступљена свега у две лекције.

3.2.3. Добра страна датог уџбеника у фонетском погледу јесте у увођењу фонетске транскрипције: аутори минимизирају степене редукције - два степена редукције су сведена на један, реализације [а] после тврдих сугласничких гласова и [и] после ме- 
ких. Нема квадратних заграда (синонима за фонетску транскрипцију), али је начином обележавања знакова транскрипције (само спољна линија знака је оцртана) адекватно постигнута дистинкција слово - глас; самогласнички гласови су дати црвеном бојом, редуковани гласови су визуелно смањени (двоструко су мањи од пуних вокалских гласова); сугласнички гласови су обележени плавом бојом, тако да се дистинкција слово - глас веома добро визуелно усваја, као и дистинкција самогласник - сугласник.

3.2.4. Аутори нису довољно пажње посветили кључној сегментној доминанти, неопходној за правилно усвајање прозодијских, а то је изговор руских палатализованих гласова. Неопходно би било на датом узрасту увежбавати сегментне доминанте које се односе на парне тврде/меке сугласничке гласове. Дата доминанта би требало да се провлачи бар кроз половину лекција (у датом случају три лекције) и да буде увежбавана непосредно (усвајање изговора палатализованих гласова) и посредно (кратки дијалози, текстови у којима су заступљени палатализовани сугласнички гласови у различитим позицијама).

\section{3. Родничок 6}

3.3.1. Као и у претходном комплету, врло је мали удео специјалног фонетског материјала, који у просеку заузима око 1,5 минут по часу. За разлику од претходног комплета, овде свака лекција садржи специјални фонетски материјал. У свим лекцијама доминирају неспецијалне фонетске вежбе, а сав фонетски неспецијални материјал равномерно је распоређен.

3.3.2. Прозодијски материјал заузима свега приближно 1\% укупног материјала уџбеника. Редукција вокала није обновљена, редукција вокалских гласова после меких сугласничких гласова није презентована ни у једној од лекција.

3.3.3. Аутори почињу бележење гласова у квадратним заградама (иако се задржава црвена боја за вокалске, а плава за сугласничке гласове, одступа се од начина бележења гласа спољном линијом). По нашем мишљењу, овакво бележење представља помак унапред - ближе је научном бележењу фонетске транскрипције руског језика; утврђује се дистинкција слово : глас.
3.3.4. Нема концентричности у излагању фонетског материјала: он се даје као „фонетска етикета”, епизодно, како пише Ксенија Кончаревић (2004: 133), провежбава (или не провежбава) само у једној наредној вежби и више се не обнавља.

\section{4. Родничок 7}

3.4.1. Квантитативна анализа фонетског материјала уџбеника нам показује да само три од шест лекција садрже специјални фонетски материјал, те да је укупан фонетски материјал заступљен у још мањој мери у односу на претходне уџбенике, са свега 2,4 \% у односу на целокупан уџбенички материјал. Ретка сегментна објашњења нису у овом уџбенику пропраћена одговарајућим вежбама, док малобројна прозодијска објашњења прате вежбе сличног обима. У самом приручнику има доста материјала посвећеног прозодијским доминантама, тако да приручник надопуњује, донекле, фонетски материјал који је у уџбенику присутан у минималном обиму.

3.4.2. Прозодијске доминанте које се тичу редукције вокалских гласова у више наврата се обрађују и обнављају у комплету за седми разред, што је веома позитивно; већина доминанти се, пак, даје ван самог уџбеника (у приручнику). Сматрамо да би неопходно било све доминанте планиране за обраду презентовати у самом уџбенику.

3.4.3. Фонетски материјал се, у датом комплету, обнавља: исте доминанте се наизменично обнављају у свакој лекцији, принцип концентричности излагања материје је поштован.

\section{5. Родничок 8}

3.5.1. Квантитативна анализа фонетског материјала уџбеника нам показује да се у пет од шест лекција садржи фонетски материјал. Укупан фонетски материјал заступљен у још мањој мери у односу на претходне уџбенике, са свега 2 \% у односу на целокупан уџбенички материјал. Сегментне и прозодијске вежбе надилазе квантитет самих објашњења. Вежбе се најчешће појављују самостално, односно нису праћене претходним објашњењима, што нам прелиминарно говори о чињеници да се у датом уџбенику махом обнављају фонетски садржаји. 
3.5.2. Иако је најављено обнављање градива у предговору приручника, можемо закључити да се оно односи у већој мери на граматички материјал (падежи, глаголске парадигме, глаголи кретања с бројним вежбама); фонетски материјал је такође присутан, доминантно у виду вежби, али се јавља спорадично, налик на „фонетске етикете”, залепљене понегде без неког дубљег објашњења. Материјал није систематизован.

3.5.3. Из уџбеника за осми разред нестаје фонетска транскрипција. Аутори више не користе квадратне заграде (уведене у 6. разреду) и на овај начин занемарују усвајање и дубље разумевање дистинкције „слово : глас”.

3.5.4. Иако је у предговору приручника најављена активна употреба зависносложених реченица и увођење везничких речи, оваква објашњења и вежбе се срећу тек спорадично: оне нису пратиоци сваке лекције; када се обрађује, пак, синтакса, ниједном се не указује на фонетске особености исказа: паузе, покрет мелодијског тона који представљају главни чинилац правилног фонетског уобличавања исказа. Синатакса се, као и граматика, даје изоловано од фонетике.

3.5.5. Редукција вокалских гласова која се обнавља и у седмом и осмом разреду, не обухвата нити у једном од уџбеника примере „икања”: односно изговора гласа [и] после меких сугласничких гласова, на местима писања слова $e, я, a$. Икање је далеко теже за усвајање од акања, јер се јавља и проблематика изговора меког сугласничког гласа, а затим и квалитативне редукције самогласничког гласа.

\section{6. Фреквенцијска анализа комплета Родничок}

3.6.1. Сабравши појављивање сваке од доминанти у читавом уџбеничком комплету, дошли смо до следећих закључака: сегментне доминанте имају већи број појављивања у односу на прозодијске, тај однос је приближно 91: 54 . Другим речима, готово су двоструко учесталије сегментне доминанте.

3.6.2. Међу сегментним доминантама преовлађују доминанте које се односе на меке сугласничке гласове (конкретно: [л'], [т'], [д'], [ч'], [ш:'], [j] и [с']).
3.6.3. Следе тврди сугласнички гласови (конкретно: [р], [ш], [ж], [ц], [в] и [л]);

3.6.4. За тврдим гласовима следе алтернације сугласничких гласова.

3.6.5. Тек 4 појављивања имају парни тврди/меки сугласнички гласови.

3.6.6. Звучни и безвучни помињу се само једанпут.

3.6.7. Најчешће прозодијске доминанте тичу се акцентованих и редукованих вокалских гласова. Од конкретних акцентованих гласова најчешће се понавља глас [ы].

3.6.8. Следе редукције гласова (34 појављивања од 42) после тврдих сугласничких гласова („акање”, 22 понављања); после меких гласова („икање”, 12 понављања).

3.6.9. Интонација исказа има упола мањи број појављивања у односу на вокалске гласове, тиче се доминантно једносинтагматских исказа.

3.6.10. Само једно појављивање има вишесинтагматски исказ, „интонација набрајања”. Коначно, једно појављивање има и „фонетска реч” у оквиру одељка „акценатска целина”.

\section{4. Фонетски материјал уџбеничког комплета Орбита}

\section{1. Орбита 1}

4.1.1. Врло је висок удео фонетског материјала у односу на укупан материјал уџбеника у лекцијама 5-11, 13, 15, 17 и 19. Уколико бисмо просечну вредност узели у обзир - видимо да фонетски материјал заузима око 11, 5 \% целокупног материјала. Можемо закључити да у Орбити 1 доминирају сегментна средства и јединице (у 12 лекција од 16 су присутна, што чини удео од 10,5 \% у односу на целокупни материјал уџбеника), док су прозодијске јединице и средства присутна у свега 4 лекције (свега око 1\% укупног материјала).

4.1.2. Свака лекција се, почев од прве писане лекције па до десете лекције, отвара фонетским материјалом. Без обзира на то што је овакав прилаз обради теме условљен почетним учењем, уџбеничка лекција би требало да почиње текстом, тј. да се ученици прво уведу у тему коју треба да обрађују, док наставник може да их упозори претходно на неке фонетско-словне новине, 
тј. новине приликом читања појединих речи, али сам фонетски материјал треба да буде уткан у смисаони садржај. О овоме пише и М. Н. Шутова (2004: 14); фонетски материјал мора да извире из самог садржаја лекције, односно увек би морао да има „комуникативну љуштуру”; сам текст треба да буде засићен фонетским доминантама планираним за обраду у датој лекцији.

4.1.3. Потпуна је доминација сегментних доминанти у односу на прозодијске (10,5\% према 1\%).

4.1.4. Коначно, као и уџбеничком комплету Родничок 3 који представља први комплет серије Родничок у ком се ученици описмењују, доминирају вежбе читања, а сам неспецијални фонетски материјал заузима велики удео у односу на целокупан језички материјал уџбеничког комплета.

\section{2. Орбита 2}

4.2.1. Фонетски материјал се појављује у 7 од 8 лекција. Његов удео нагло пада, нарочито када упоредимо квантитет фонетског материјала с комплетом Орбита 1. Од приближних 11,5\% удела фонетског материјала у односу на целокупан материјал уџбеника у Орбити 1, спало се на приближних 5,3\% удела фонетског материјала у материјалу уџбеника Орбита 2. Преовлађују сегментне доминанте (присутне у 7 од 8 лекција) у односу на прозодијске (присутне у само 2 од 8 лекција). Сегментне доминанте чине приближно 4\%, док прозодијске чине приближно 1\% целокупног материјала уџбеника.

4.2.2. Новину у односу на претходни комплет, као и на комплет Родничок представља начин увођења фонетског материјала путем дијалога. Својом динамичношћу и занимљивошћу сам дијалог доприноси повећању пажње код ученика, која може резултирати бољим памћењем самог материјала.

4.2.3. Први пут се у комплету Орбита 2 дају вежбе за место акцента у речи (оваквих вежби нема у уџбеницима комплета Родничок).

\section{3. Орбита 3}

4.3.1. Фонетски материјал се појављује у 7 од 8 лекција. Удео фонетског материјала опада и чини само 4,2 \% у односу на це- локупан материјал уџбеника. Нешто већи удео припада прозодијском материјалу (2,15\%), док остали део (нешто више од 2\%) чини сегментни материјал. Први пут у уџбеницима које смо до сада анализирали квантитет прозодијског материјала превазилази квантитет сегментног материјала.

4.3.2. Позитивна је и чињеница да се први пут у основношколском уџбенику руског језика појављује веома важна прозодијска доминанта која би требало да заузима централни концентар у настави прозодије - интонација унутрашњих фонетских синтагми и ИК-З. Аутори презентују исказе изоловано; не можемо знати у којим околностима и ком стилу су употребљени, шта им претходи и следи, што нас наводи на следеће запажање: када се презентује једна интонациона конструкција, морали бисмо је примарно дати у мини-контексту - исказ који нам служи као модел за одређено кретање тона мора имати бар једну реплику (уколико је дијалог) или још један исказ испред и иза себе (ако се ради о монологу). Он мора бити контекстуализован. О овоме су писале и Н. Е. Луцка (1983) и Д. Н. Антонова (1975: 60).

4.3.3. Сегментне доминанте се углавном обнављају. И њих карактерише непрецизност фонетског израза. Школска фонетска транскрипција замењена је транскрипцијом блиском научној, што представља позитивну промену.

\section{4. Орбита 4}

4.4.1. Фонетски материјал постоји у свакој лекцији. Удео фонетског материјала у односу на целокупан материјал уџбеника исти је као и у претходном уџбеничком комплету $(4,15 \%)$. У датом комплету доминира сегментни материјал, док прозодијски обухвата тек 0,66\% целокупног материјала уџбеника. Примећујемо и да су процентуално заступљеније сегментне вежбе у односу на претходне комплете, јер приближно 1,8\% укупног материјала уџбеника припада сегментним објашњењима, док 1,7\% чине сегментне вежбе (удео објашњења и вежби је готово исти).

4.4.2. Први пут се појављују прозодијске доминанте у вези с местом акцента у речима истог словног састава, или различитим облицима исте речи. 
4.4.3. Први пут се у уџбеницима за основну школу појављује алтернација гласа [и] с гласом [ы] после тврдих сугласничких гласова.

\section{5. Фреквенцијска анализа комплета Орбита}

4.5.1. Сегментне доминанте имају готово двоструко већи број појављивања у односу на прозодијске, тај однос приближно je $56: 30$.

4.5.2. Највећи број појављивања имају меки сугласнички гласови, доминанта 1.2. (најчешћи је глас [j], следе [ч'] и [ш']; укупно 22 пута.

4.5.3.Тврди гласови имају 20 појављивања (најчешћи су [ж], [ш] и [ц]).

4.5.4. Тек шест појављивања имају парни тврди и меки сугласнички гласови.

4.5.5. Алтернације сугласничких гласова се појављују 4 пута.

4.5.6. Звучни и безвучни гласови појављују се само једанпут у читавом комплету.

4.5.7. Најчешће прозодијске доминанте тичу се акцентованих вокалских гласова са дванаест појављивања и редукованих вокалских гласова са само 4 појављивања; најчешћи акцентовани глас је глас [ы], најчешће презентован у контрасту с гласом [и].

4.5.8.Тематика посвећена месту акцента у речи у ужем смислу појављује се четири пута у читавој серији уџбеника.

4.5.9. Интонација исказа има упола мањи број појављивања у односу на вокалске гласове, тиче се доминантно једносинтагматских исказа.

4.5.10. Само једно појављивање има вишесинтагматски исказ, представљен интонацијом унутрашње синтагме двосинтагматског исказа.

\section{5. Фонетски материјал уџбеника}

\section{у коауторству Петра Митропана}

5.1. Уџбеници шездесетих и седамдесетих година настали су у коауторству Петра Митропана и других аутора. Дати уџбеници не представљају уџбенички комплет, намењени су средњош- колском продужном и почетном учењу руског језика. Њихова анализа има за циљ да нам укаже на сличности и разлике у квантитету, квалитету и фреквенцији тематизованог фонетског и прозодијског материјала између уџбеника различитих година настајања. Пошто су два уџбеника намењена почетном учењу могу се поредити с актуелним уџбеничким комплетима за основну школу.

5.2. Уџбеник 1962 и Уџбеник 1970 су уџбеници за пету годину учења. Фонетски материјал је заступљен минимално, са 0,86 \% у Уџбенику 1962 и готово двоструко већим процентом у Уџбенику 1970 (1,8\%). Уџбеник 1971 је уџбеник за прву годину учења и самим тим је удео фонетског материјала у укупном материјалу уџбеника много већи у односу на остале уџбенике $(6,5 \%)$. Већ у наредном уџбенику за другу годину учења, квантитет фонетског материјала опада петоструко и износи скромних 1,38\%. Уколико бисмо дата два уџбеника упоредили с комплетом Орбита (уџбеницима Орбита 1 и Орбита 2), могли бисмо закључити да је у модерним уџбеницима руског језика за почетно учење (прва и друга година) квантитет фонетског материјала двоструко већи $(11,5 \%$ у Орбити 1, 5,3\% у Орбити 2). Модерне уџбенике руског језика одликује и бољи квантитативни статус пратећег фонетског курса, који је у другој години учења заступљен са готово истим процентом као у уџбеницима седамдесетих година за прву годину учења.

Као и у модерним уџбеницима, заступљенија су фонетска објашњења у односу на вежбе, осим у Уџбенику 1970, у ком доминирају вежбе. Прозодијски материјал заступљен је у сва три уџбеника седамдесетих година, с тим што је његов удео много мањи у односу на конкретан сегментни материјал (осим у Уџбенику 1970).

5.3. Уџбеници се одликују непрецизношћу фонетског израза, мешањем појмова „слово : глас” (сличне непрецизности постоје и у модерним уџбеницима руског језика). Фонетске непрецизности се продубљују, аутори мешају појам „слово:глас”; непрецизност прелази и на виши ниво - мек или тврд глас из истог пара, по ауторима, припада истој фонеми.

5.4. Уџбеници, поготово Уџбеник 1970, тематизује самостална прозодијска објашњења и вежбе, што га сврстава раме уз раме с модерним уџбеницима руског језика почетка XXI века. 
5.5. Фонетски материјал је много несамосталнији у односу на фонетски материјал модерних уџбеника руског језика; поједине фонетске теме се најчешће дају уз граматичка објашњења, док сам фонетски материјал није повезан са централним, комуникативно-лексичким делом лекције.

5.6. У уџбеницима се неупотребљава фонетска транскрипција која је презентована у свим модерним уџбеницима руског језика.

5.7. Фонетски материјал је само у почетном уџбенику самосталан, свака лекција се отвара текстом који је засићен конкретним фонетским доминантама. Сматрамо да је овај принцип (отварање текстом) много бољи него принцип отварања фонетским објашњењем (као у модерном почетном уџбенику Орбита 1), после ког следи текст, јер се прво конкретизује проблем - а онда разреши, односно објасни.

\section{6. Фреквенцијска анализа уџбеника} у коауторству Петра Митропана

6.1. Сегментне и прозодијске доминанте се по броју појављивања приближавају, 52 пута се поноваљају сегментне, 36 пута прозодијске. Према односу сегментних и прозодијских доминанти (1,44 пута су чешће сегментне) уџбеници шездесетих и седамдесетих година су, рекли бисмо, напреднији у односу на модерне уџбенике руског језика за основну школу.

6.2. Највећи број појављивања имају тврди сугласнички гласови, најчешћи су [ж], [ш] и [ц]; укупно 24 појављивања.

6.3. Меки гласови имају 17 појављивања (најчешћи су [j], [ш':] и [ч'])

6.4. Четири појављивања се везује за алтернације гласова.

6.5. Меки и тврди сугласнички гласови се понаваљају само три пута.

6.6. Најчешће прозодијске доминанте тичу се вокалских гласова (27 појављивања), и то су најчешћи акцентовани вокалски гласова са осам појављивања и редуковани вокалски гласови са само 4 појављивања; најчешћи акцентовани глас је глас [ы]; дати уџбеници су по овој особини готово идентични с модерним уџбеницима руског језика.
6.7. Тематика посвећена месту акцента у речи појављује се свега шест пута у у уџбеницима.

6.8. Интонација исказа има троструко мањи број понављања у односу на вокалске гласове, тиче се доминантно једносинтагматских исказа.

\section{7. Доминанте модерних уџбеника у поређењу са уџбеницима шездесетих и седамдесетих година. ФОНЕТСКИ СТЕРЕОТИП}

7.1. У модерним уџбеницима су нешто заступљеније сегментне доминанте које се односе на појединачне меке сугасничке гласове (то су у свим уџбеницима доминантно гласови [ч'], [j] и [ш'], заједно поновљени 82 пута од укупног броја појављивања свих сегментних доминанти у свим анализираним уџбеницима - 197) док су у уџбеницима шездесетих и седамдесетих година нешто заступљеније доминанте које се односе на појединачне тврде сугласничке гласове (и у модерним уџбеницима и у уџбеницима 60-их и 70-их година то су гласови [ж], [ш], [ц] и [л], заједно поновљени 74 пута од 197 пута). Врло ретко се појављује доминанта која се односи на опозицију тврд/мек сугласнички глас у обе генерације уџбеника (13 од 197 појављивања), а дата доминанта би по учесталости у говору и утицају на акцентоване вокалске гласове, односно својој прозодијској тежини, требало да представља централну доминанту наставе фонетике.

7.2. Када уопштимо прозодијске доминанте датих уџбеника, видимо да се највећи број појављивања односи на акцентоване вокалске гласове, нарочито на акцентовани глас [ы] (њему је посвећено 16 појављивања од укупних 28 појављивања акцентованих вокалских гласова).

7.3. Прозодијске доминанте које се тичу интонације исказа су минимално заступљене у обе генерације уџбеника руског језика (свега 30 појављивања у оквиру прозодијских доминанти у односу на укупних 120 појављивања).

7.4. Узевши у обзир доминантни сегментни и прозодијски материјал анализираних уџбеника руског језика, можемо закључити да се централно место придаје гласовима [ч'], [j], [ш'], [ж], 
[ш], [ц], [Л] и [Ы], те из овога изводимо појам ФОНЕТСКОГ СТЕРЕОТИПА, који чине поменуте сегментне и прозодијске доминанте. Зашто фонетски стереотип? Сматрамо да поменуте доминанте ни у ком случају не треба да представљају централно место у настави фонетике и да имају највећу учесталост појављивања. Они су традиционално били најзаступљенији у старијој генерацији уџбеника, па се то у наредном периоду (сваки следећи уџбеник се ослањао на претходни) почело понављати. Отуда фонетски стереотип доминира и у новијој генерацији уџбеника. Стереотип је да ове доминанте треба да заузимају централно место наставе фонетике у српској говорној средини. Извор датог стереотипа лежи у чињеници да се у гласовним системима два језика ове разлике најјасније уочавају: имамо пандане датих („истих") гласова у оба језика, али различит њихов квалитет, недовољна тврдоћа/мекоћа приликом изговора ученика најпре (али и најлакше) упада у очи. Сматрамо да модерни уџбеници руског језика морају заменити најфреквентније доминанте: уместо фонетског стереотипа, најучесталије треба да буду бинарне опозиције тврд/мек сугласнички глас, да за њима следе прозодијске доминанте: акцентовани и редуковани вокалски гласови, те ИК-3 и навике сегментације.

\section{ЦИТИРАНА ЛИТЕРАТУРА}

Антонова, Д. Н. „О сопроводительном курсе фонетики и интонации в учебнике русского языка для иностранцев.” Русский язык за рубеЖом, № 2 (1975): 59-62.

Ахманова, О. С. Словарь лингвистических терминов. Москва: Советская энциклопедия, 1966.

Князев, С. В. Пожарицкая С. К. Современный русский литературный язык. Фонетика, графика, орфография, орфоэпия. Москва: Академический Проект, 2005.

Князев, С. В. Пожарицкая С. К. Современный русский литературный язык. Фонетика, графика, орфография, орфоэпия. Москва: Академический Проект; Гаудеамус, 2011.

Кодзасов, С. В. Кривнова, О. Ф. Общая фонетика. Москва: Российский государственный гуманитарный университет, 2001.
Кончаревић, Ксенија. Савремена настава руског језика. Садржаји. Организација. Облици. Београд: Славистичко друштво Србије, 2004.

Корниенко, Е. Р. „Вводно-фонетический курс в системе обучения иностранных учащихся русскому языку." Русский язык за рубежом, № 2-3 (1995): 52-58.

Логинова, И. М. „Концепция Е. А. Брызгуновой. Традиции и новаторство." Вопросы русского языкознания. Вып. XI. Аспекты изучения звучащей речи. Сборник научных статей к юбилею Е. А. Брызгуновой. (2004): 12-26.

Луцкая, Н. Э. „Работа над ритмикой и интонацией русской диалогической речи.” Русский язык за рубежом, № 3(1983): 35-41.

Шутова, М. Н. „Фонетический курс русского языка для иностранных студентов-филологов на завершающем этапе обучения." Русский язык за рубежом, № 4 (2004): 12-16.

\section{ИЗВоРИ}

Поповић, Љ, Гинић, Ј. Родничок 1. Руски језик за йрви разреg основне школе. Београд: Завод за уџбенике и наставна средства, 2003.

Поповић, Љ, Гинић, Ј. Родничок 1. Руски језик. Раяна свеска. Београд: Завод за уџбенике и наставна средства, 2003.

Поповић, Љ, Гинић, Ј. Родничок 1. Руски језик. Приручник за насйавнике. Београд: Завод за уџбенике и наставна средства, 2003.

Поповић, Љ, Гинић, Ј.Родничок 2. Руски језик за друїи разреg основне школе. Београд: Завод за уџбенике и наставна средства, 2004.

Поповић, Љ, Гинић, Ј.Родничок 2. Руски језик. Раgна свеска. Београд: Завод за уџбенике и наставна средства, 2003.

Поповић, Љ, Гинић, Ј. Родничок 2. Руски језик. Приручник за насииавнике. Београд: Завод за уџбенике и наставна средства, 2003.

Поповић, Љ, Гинић, Ј. Родничок З. Руски језик за йрећи разреg основне школе. Београд: Завод за уџбенике и наставна средства, 2005.

Поповић, Љ. Гинић, Ј. Родничок З. Руски језик. Раяна свеска. Београд: Завод за уџбенике и наставна средства, 2005.

Поповић, Љ. Гинић, Ј. Родничок 3. Руски језик. Приручник за насииавнике. Београд: Завод за уџбенике и наставна средства, 2005.

Гинић Ј. Тешић А. Родничок 4. Руски језик за чейвриии разреg основне школе. Београд: Завод за ушбенике и наставна средства, 2006.

Гинић J. Тешић А. Родничок 4. Руски језик. Раяна свеска. Београд: Завод за уџбенике и наставна средства, 2006.

Гинић Ј. Тешић А. Родничок 4. Руски језик. Приручник за насииавнике. Београд: Завод за уџбенике и наставна средства, 2006. 
Поповић, Љ. Гинић, Ј. Родничок 5. Руски језик за иееии разреg основне школе. Београд: Завод за уџбенике и наставна средства, 2007.

Поповић, Љ. Гинић, Ј. Родничок 5. Руски језик. Раяна свеска. Београд: Завод за уџбенике и наставна средства, 2007.

Поповић, Љ. Гинић, Ј. Родничок 5. Руски језик. Приручник за настиавнике. Београд: Завод за уџбенике и наставна средства, 2007.

Поповић, Љ. Гинић, Ј. Родничок 6. Руски језик за шестии разреg основне школе. Београд: Завод за уџбенике, 2008.

Поповић, Љ. Гинић, Ј. Родничок 6. Руски језик. Раgна свеска. Београд: Завод за уџбенике, 2008.

Поповић, Љ. Гинић, Ј. Родничок 6. Руски језик. Приручник за насйавнике. Београд: Завод за уџбенике, 2008.

Поповић, Љ. Гинић, Ј. Родничок 7 Руски језик за сеgми разреg основне школе. Београд: Завод за уџбенике, 2009.

Поповић, Љ. Гинић, Ј. Родничок 7. Руски језик. Раяна свеска. Београд: Завод за ушбенике, 2009.

Поповић, Љ. Гинић, Ј. Родничок 7. Руски језик. Приручник за насйавнике. Београд: Завод за уџбенике, 2009.

Поповић, Љ. Гинић, Ј. Родничок 8. Руски језик за осми разреg основне школе. Београд: Завод за уџбенике, 2010.

Поповић, Љ. Гинић, Ј. Родничок 8. Руски језик. Раgна свеска. Београд: Завод за уџбенике, 2010.

Поповић, Љ. Гинић, Ј. Родничок 8. Руски језик. Приручник за настиавнике. Београд: Завод за уџбенике, 2010.

Пипер, П. Петковић, М. Мирковић С. Орбита 1. Руски језик за йейи разреg основне школе. Београд: Завод за уџбенике, 2007.

Пипер, П. Петковић М. Мирковић С. Орбита 1. Руски језик. Раqна свеска за иееии разреg основне школе. Београд: Завод за уџбенике, 2007.

Пипер, П. Петковић, М. Мирковић С. Орбита 1. Руски језик. Приручник за настиавнике за иеети разреg основне школе. Београд: Завод за уџбенике, 2007.

Пипер, П. Петковић, М. Мирковић, С. Орбита 2. Руски језик за шесии и разреg основне школе. Београд: Завод за уџбенике, 2008.

Пипер, П. Петковић, М. Мирковић, С. Орбита 2. Руски језик. Раgна свеска за шести и разреg основне школе. Београд: Завод за уџбенике, 2008.

Пипер, П. Петковић, М. Мирковић, С. Орбита 1. Руски језик. Приручник за настиавнике за шестии разреg основне школе. Београд: Завод за уџбенике, 2008.

Пипер, П. Петковић, М. Мирковић, С. Орбита 3. Руски језик за сеgми разреg основне школе. Београд: Завод за уџбенике, 2009.
Пипер, П. Петковић, М. Мирковић, С. Орбита 3. Руски језик. Раgна свеска за сеgми разред основне школе. Београд: Завод за уџбенике, 2009.

Пипер, П. Петковић, М. Мирковић, С. Орбита 3. Руски језик. Приручник за настиавнике за сеgми разреg основне школе. Београд: Завод за уџбенике, 2009.

Пипер, П. Петковић, М, ., С. Орбита 4. Руски језик за осми разреg основне школе. - Београд: Завод за уџбенике, 2010.

Пипер, П. Петковић, М. Мирковић, С. Орбита 4. Руски језик. Раgна свеска за осми разреg основне школе. - Београд: Завод за уџбенике, 2010.

Пипер, П. Петковић, М. Мирковић, С. Орбита 4. Руски језик. Приручник за настиавнике за осми разред основне школе. Београд: Завод за уџбенике, 2010

Ридановић, Љ. Митропан, П. Руски језик за йрви разреg їимназије. Београд: Завод за издавање уџбеника Народне републике Србије, 1962.

Живковић-Штефан Љ. Митропан, П. Руски језик за ирви разреg іимназије. Београд: Завод за издавање уџбеника Социјалистичке републике Сpбије, 1970.

Станојевић Р. Митропан П. Руски језик за ученике іиманзија. Београд: Завод за издавање уџбеника Социјалистичке републике Србије, 1971.

Станојевић Р. Митропан П. Руски језик за ученике іиманзија. Београд: Завод уџбенике и наставна средства Србије, 1972.

\section{ФОНЕТИЧЕСКИЙ СТЕРЕОТИП И УЧЕБНИКИ} РУССКОГО ЯЗЫКА В СЕРБИИ

Фонетический материал для нашего исследования извлечен из актуальных учебников русского языка в восьмилетних школах Сербии: из комплекта учебников Орбита, русский язык - второй иностранный язык и из комплекта учебников по русскому языку Родничок (первый иностранный язык). Фонетический материал был извлечен и из учебников «старшего поколения»- учебников 60-х и 70-х годов XX века, соавтором которых был Петр Митропан. С ними мы сравнивали современные учебники по следующим параметрам: количество качество и частотность фонетического материала. Из приведнных выше комплектов мы выписывали фонетический материал, касающийся фонетических объяснений и упражнений, подвергая его количественному, качественному и частотному анализу. Задача количественного анализа - показать долю фонетического материала в совокупном материале учебника, причём мы разграничили сегментный и суперсегментный фонетический материал; задача качественного анализа - показать качество фонетических объяснений и упражений, касающихся фонетики; задача частотного анализа - указать на то, какой именно фонетический материал доминирует в конретном комплекте учебников. 
Имея в виду доминирующий сегментный и суперсегментный материал данных комплектов учебников, мы пришли к выводу, что центральное место отдается звукам [ч'], [j], [ш':], [ж], [ш], [ц], [л] и [ы], которые мы назвали фонетическим стереотипом. Мы считаем, что хотя и важно овладеть данными звуками, они по количеству и частотности не должны занимать центральное место. Они традиционно занимали центральное место в учебниках старшего поколения; учебники нового поколения, продолжая опыт предыдущих учебников, снова отводят им слишком значительное место. И в русском и в сербском языках присутствует большинство приведенных звуков, различие заключается лишь в качестве. Нужно, конечно, обращать на это внимание учеников. Современные учебники должны уделить особое внимание количеству и частоте употребления следующего фонетического материала: оппозиции твердый/мягкий согласный, ударный/редуцированный гласный, ИК-3 и типичному синтагматическому членению в высказываниях русского языка. Приведненные особенности русской артикуляционной базы очень трудно усваиваются носителями сербского языка, ибо в сербском языке они отсутствуют.
Нина Говедар ${ }^{1}$

Универзитет у Бањој Луци

821.163.41.09-31 Андрић И.

Филолошки факултет

https://doi.org/10.18485/mks_knsjkk.2017.ch6

\section{НАРАТОЛОШКИ ПРИСТУП РОМАНУ ПРОКЛЕТА АВЛИЈА У УНИВЕРЗИТЕТСКОЈ НАСТАВИ И МОГУЋНОСТИ ИНТЕРПРЕТАЦИЈЕ У СРЕДЊОШКОЛСКОЈ НАСТАВИ}

У овом раду ћемо се бавити могућностима тумачења романа Проклет̄а авлија са аспекта посткласичне наратологије, те разматрањем различитих аспеката које такав приступ омогућава при интерпретацији дјела у универзитетској настави. Своје интересовање усмјеравамо на могућности рада са студентима студијских програма за српски језик и књижевност, наставничког смијера. Циљ нам је да сагледамо што више могућности за што квалитетнију интерпретацију наведеног књижевног дјела у универзитетској настави. Такође, у раду ћемо се посебно осврнути на могућности методичке интерпретације романа Проклейа авлијау средњошколској настави, а на основу датог наратолошког тумачења.

Кључне ријечи: Проклет̄а авлија, когнитивна наратологија, могућности тумачења, универзитетска настава, средњошколска настава, наставна интерпретација књижевног дјела.

\section{1. Увод}

Књижевно дјело Иве Андрића свакако је један од најзначајнијих сегмената наше књижевне баштине. Својим вишеструким литерарним, естетским и универзално-животним вриједностима и дан-данас једнако привлачи и читаоце и проучаваоце. Вишеслојност коју његова дјела носе као општу одлику допушта нам да им приђемо са небројено много аспеката, откривајући сваки пут нове вриједности и нове могућности за тумачење.

Један од таквих приступа који се развио у савременом посттеоријском (према Иглтону), односно посткласичном (према Херману), виртуелној реалности окренутом друштву, јесте пост-

\footnotetext{
${ }^{1}$ nina.govedar@flf.unibl.org
} 